\title{
NEW RULES FOR CORPORATE GOVERNANCE IN THE UNITED STATES AND GERMANY - A MODEL FOR NEW ZEALAND?
}

\author{
Oliver Krackhardt
}

This paper surveys the possibilities for implementing new rules for corporate governance in New Zealand. It focuses on the new rules issued in Germany (the German Code of Corporate Governance) and the United States (the Sarbanes-Oxley Act). The paper analyses both to find out which rules might be appropriate for New Zealand. It is argued that New Zealand needs to adopt a code of corporate governance in order to keep up with international developments, otherwise it risks repelling local investors and failing to attract international investors. It is concluded that most importantly New Zealand should adopt a principles-based "comply-or-explain" approach rather than strict rules, as it offers greater flexibility. The paper further concludes that many of the rules issued in Germany and the United States could improve corporate governance in New Zealand and hence should be implemented.

\section{INTRODUCTION}

Currently corporate governance is one of the hottest topics of corporate law. Throughout the world new systems are being discussed and developed. Predominant countries like the United States, Germany and the United Kingdom have issued new rules in recent years. Most notably for New Zealand, its closest neighbour Australia has adopted a code of corporate governance as have smaller nations like Slovakia, Denmark, and Kenya. The question for smaller countries is how to keep up in the global competition for international investors' capital. This question will be addressed considering the example of New Zealand. Does a small country like New Zealand need special rules at all? Can it afford to find an individual way without its system being labelled out of fashion? And which way would be the most desirable?

* LLM (VUW) Research and Teaching Assistant, Bucerius Law School, Hamburg. Submitted as part of the LLM programme at Victoria University of Wellington. 
At the moment, New Zealand is developing new corporate governance principles. Therefore, it is timely to analyse and discuss certain rules and approaches that have been adopted by other countries. This paper will focus on recent changes in the United States and Germany. The purpose of the paper is to analyse the new rules for corporate governance in the United States - the Sarbanes-Oxley Act - and in Germany - the German Code of Corporate Governance - in order to find out which of these rules might be appropriate for adopting in New Zealand. ${ }^{1}$

The paper will introduce the different corporate systems in the United States and Germany and identify their most significant differences. It will take a closer look at the new rules issued in both countries, emphasising the different purposes. After that, the status quo of New Zealand corporate governance will be briefly outlined. It will be concluded that New Zealand needs to issue a code of corporate governance in order to keep up with international developments and to attract international investors. The main part of the paper will focus on the most discussed topics and analyse which of the rules implemented in Germany and the United States are suitable for New Zealand, keeping in mind its specific needs. The paper will argue that some rules do not serve their purposes and therefore are not worth copying. It will be concluded that New Zealand should adopt several of the internationally favoured rules as a principle-based "comply-or-explain" approach, in order to achieve a flexible solution, while still responding to international investors' demands.

\section{LIMITING THE SCOPE}

In recent years corporate governance has become a widely discussed issue in boardrooms, governments and among scholars. Following the corporate collapses of Enron and WorldCom in the United States, HIH Insurance and OneTel in Australia, along with others, people throughout the corporate world began to rethink the fundamentals of corporate governance. Enron has been analysed as a failure of corporate governance. ${ }^{2}$ Enron's management consistently used "the most aggressive" accounting methods that were misleading and veiled Enron's true financial situation. ${ }^{3}$ Its board failed to supervise and monitor Enron's management effectively. Its accountants were deeply involved in other business with Enron and therefore lost their objectivity. Since Enron was not an isolated incident, it provided an incentive to analyse and rethink the way that business should be governed and managed. In response, new regulations were developed around the world. ${ }^{4}$

1 Sarbanes-Oxley Act (Public Company Accounting Reform and Investor Protection Act) 2002, Pub L $107-$ 204 (USA); German Code of Corporate Governance 2002 (German Code).

2 Janis Sarra "Rose-Colored Glasses, Opaque Financial Reporting, and Investor Blues: Enron as Con and The Vulnerability of Canadian Corporate Law" (2002) 76 St John's L Rev 715, 716.

3 Robert W Hamilton "The Crisis in Corporate Governance: 2002 Style" (2003) 40 Hou L Rev 1, 8.

4 For an overview, containing corporate governance codes or codes of best practice from more than 35 nations, see < http://www.kesteven.com.au/governance/codes.htm> (last accessed 17 July 2005). 
Due to the huge number of new codes and regulations, ${ }^{5}$ the scope of this paper must be limited in order to permit a sufficiently deep discussion of some of the most important questions. The influences and implications of the Australian and United Kingdom regulations on New Zealand have been analysed by various entities. Therefore, this paper will take a different approach and focus on the German and the United States regulations and analyse their approaches in order to draw conclusions for New Zealand. These systems are chosen for two main reasons. Firstly, they represent the two basic different possible approaches. While the United States response to corporate failures is rule-based, the German response represents a principles based "comply-or-explain" solution. Secondly, the two systems represent two different corporate systems in capitalist economies. ${ }^{6}$ While the United States corporate system is shareholder value dominated, the German system is the stakeholder dominant approach.

It is impossible to cover all topics within the scope of this paper. Therefore, the paper will focus on certain topics that have been approached in the recent discussion about New Zealand corporate governance reform and certain issues that particularly arise from the comparison between German and United States rules.

\section{CORPORATE GOVERNANCE IN THE UNITED STATES}

In order to understand the new rules of corporate governance in the United States, the general situation before their implementation will be explained briefly. After that, the reasons for their implementation will be highlighted.

\section{A The Situation pre Enron}

The United States' corporate system is characterised by a single-tier board (board of directors). ${ }^{7}$ Stock is widely held. There are usually no majority shareholders. ${ }^{8}$ Therefore directors are very powerful, especially the Chief Executive Officer (CEO). ${ }^{9}$ In other words, there is a separation between ownership and control. ${ }^{10}$ Consequently, one of the major goals of the United States

5 Wolff speaks of "global code fever", see Lutz-Christian Wolff "Law as a Marketing Gimmick - The Case of The German Corporate Governance Code" (2004) 3 WAUGSLR 115, 120.

6 Thomas J André "Cultural Hegemony: The Exportation of Anglo-Saxon Corporate Governance Ideologies to Germany" (1998) 73 Tul L Rev 69, 105.

7 Susan-Jacqueline Butler "Models of Modern Corporations: A Comparative Analysis of German and US Corporate Structures" (2000) 17 Ariz J Int'l \& Comp L 555, 561.

8 Sanford M Jacoby "Corporate Governance In Comparative Perspective: Prospects for Convergence" (2000) 22 CLLPJ 5, 6 ["Corporate Governance in Comparative Perspective: Prospects For Convergence"].

9 Mark J Roe "Some Differences In Corporate Structure in Germany, Japan, and The United States" (1993) 102 YLJ 1927, 1936.

10 Butler, above n 7, 587 
corporate legislation is to control the power of directors and protect minority shareholders' rights. ${ }^{11}$ Many of the United States corporate law rules are designed for that purpose. The predominant concept in United States corporate law is shareholder primacy. ${ }^{12}$ The purpose of the corporation is to earn money for the shareholders. Other stakeholders' rights are not taken into account. ${ }^{13}$

Prior to the recent scandals, United States scholars saw United States' corporate law as superior. ${ }^{14}$ The United States economy had seen a decade of continuing growth. ${ }^{15}$ Hence, the shock about apparent failures of the system was even more startling. That may explain in part the radical reaction of implementing several new regulations in a very short period of time. The most significant being the implementation of the Sarbanes-Oxley Act.

\section{B The Sarbanes-Oxley Act}

The situation in the United States changed significantly with the implementation of the Sarbanes-Oxley Act 2002 (the Act).

The Act is a response to the latest scandals in United States companies, involving Enron, WorldCom and Tyco. ${ }^{16}$ After these scandals there was high pressure on the legislature to improve corporate law in order to avoid such scandals in the future. ${ }^{17}$ A United States Senator, Paul A Sarbanes, ${ }^{18}$ and Representative, Michael Oxley, developed a catalogue of new rules designed to improve corporate governance. The Act was the result of these efforts. ${ }^{19}$ In order to fulfil the desires of angry investors the Act implemented many new, and very strict, requirements. ${ }^{20}$

11 Gustavo Visentini "Compatibility and Competition Between European and American Corporate Governance: Which Model of Capitalism?" (1998) 23 Brook J Int'l L 833, 841.

12 C A Harwell Wells "The Cycles of Corporate Social Responsibility: A Historical Retrospective for the Twenty-First Century" (2002) 51 UMKC L Rev 77, 78.

13 Sanford M Jacoby "Employee Representation and Corporate Governance: A Missing Link" (2001) 3 UPAJLEL 449, 475 ["A Missing Link"].

14 Brett H McDonnell "Convergence in Corporate Governance - Possible, But Not Desirable" (2002) 47 Vill L $\operatorname{Rev} 341,346$.

15 Hamilton, above n 3, 6.

16 To name just the larger ones.

17 Kathryn Stewart Lehman "Executive Compensation Following The Sarbanes-Oxley Act Of 2002" (2003) 81 NCLR 2115, 2117.

18 Hamilton, above $\mathrm{n} 3$.

19 Stewart Lehman, above n 17, 2117-2118.

20 Brian Kim "Sarbanes-Oxley Act" (2003) 40 Harv J Legis 235, 236. 
The Act represents the most comprehensive securities legislation in the United States since the 1930s. ${ }^{21}$ It extends beyond securities law and corporate governance and affects many areas of business conduct. The rules affect managers and directors as well as accountants and lawyers. In sum, it can be said that every person in a position to monitor a company, is now responsible to do so. It was the first time the Federal government reached into the area of corporate governance that was previously a matter reserved for the States and the State courts. ${ }^{22}$ The Federal government wanted to implement more control over all responsible persons in order to prevent corporate governance failures in the future.

The Act has a very strict rule-based approach and was signed into law on $30 \mathrm{July} 2002 .{ }^{23}$ It was drafted without further surveys and without the involvement of the business community. ${ }^{24}$ The most important rules will be discussed in detail when evaluating the sense of implementing them in New Zealand. As will be shown, some of them arguably overshoot the mark.

\section{CORPORATE GOVERNANCE IN GERMANY}

Before discussing the new rules in German corporate governance, the general situation as well as the reason for their implementation will be outlined.

\section{A The Situation before the Corporate Governance Code 2002}

German corporate law is characterised by a two-tier board system. ${ }^{25}$ Beside the managing board (Vorstand) there is a second board, called the supervisory board (Aufsichtsrat). ${ }^{26}$ The managing board is responsible for representing the company and conducting its affairs. ${ }^{27}$ For the day-to-day conduct of business it often appoints executives. ${ }^{28}$ The supervisory board is not involved in day-today business. Its main function is monitoring the managing board. ${ }^{29}$ Half of the members of the

21 Stewart Lehman, above n 17, 2118.

22 Douglas M Branson "Enron - When All Systems Fail: Creative Destruction or Roadmap to Corporate Governance Reform?" (2003) 48 Vill L Rev 989, 989.

23 Kim, above n 20, 235-236.

24 Hamilton, above n 3, 46 .

25 Peter Burbidge "Creating High Performance Boardrooms and Workplaces - European Corporate Governance in the Twenty First Century" (2003) 28 EL Rev 642, 651.

26 Franck Chantayan "An Examination of American and German Corporate Law Norms" (2002) 16 St John's J Legal Comment 431, 436-437.

27 Mahmut Yavasi "Shareholding and Board Structures of German and UK Companies" (2001) 22 Comp Law $47,48$.

28 Chantayan, above n 26, 441 .

29 Butler, above n 7, 564. 
supervisory board are elected at the general shareholder meeting. ${ }^{30}$ The second half of the supervisory board consists of employee representatives. ${ }^{31}$ This reflects the German system of codetermination. ${ }^{32}$ However, despite the fact that there is an even number of employee-elected and shareholder-elected representatives on the board, there is only "quasi-parity", because the chairman, who is elected by the shareholders, has a casting vote. ${ }^{33}$ Nevertheless, the mandatory involvement of employees in governing a corporation shows that German company law goes beyond the interest of shareholders and takes other stakeholders' interests into account as well. ${ }^{34}$

The shareholder structure should also be mentioned. As in some other European countries, ${ }^{35}$ stock in Germany is held by some large, often majority, shareholders. ${ }^{36}$ For example, eighty per cent of the top 170 firms listed in Germany had at least one shareholder owning at least twenty-five per cent of the shares in the late $1990 \mathrm{~s} .{ }^{37}$ Fifty-seven per cent even had a majority shareholder. ${ }^{38}$ The shareholding structure influences corporate governance. The large shareholders have significant control over directors' powers. ${ }^{39}$ Consequently, one of the big problems for German corporate law is controlling the power of these major shareholders. ${ }^{40}$

30 Hans-Christoph Hirt "The Review of the Role and Effectiveness of Non-Executive Directors: A Critical Assessment with Particular Reference to the German Two-Tier Board System: Part II" (2003) 14 ICCLR 261, 269 ["The Review of the Role"].

31 Roberta Romano "A Cautionary Note on Drawing Lessons From Comparative Corporate Law" (1993) 102 YLJ 2021, 2031.

32 Butler, above n 7, 561-562.

33 Hans-Christoph Hirt "Germany: The German Corporate Governance Code: Co-Determination and Corporate Governance Reform" (2002) 23 Comp Law 349, 352 ["Germany: The German Corporate Governance Code"].

34 Burbidge, above n 25, 642-643.

35 For example France and Italy; Visentini, above n 11, 836.

36 Often banks; Franklin A Gevurtz "The Globalization of Corporate and Securities Law: An Introduction to a Symposium, and an Essay on the Need for a Little Humility When Exporting One's Corporate Law" (2002) 16 Transnat'l Law 1, 3.

37 Janis Sarra "Convergence Versus Divergence, Global Corporate Governance at the Crossroads: Governance Norms, Capital Markets \& OECD Principles for Corporate Governance" (2002) 33 Ottawa L Rev 180, 196 ["Convergence Versus Divergence"].

38 Yavasi, above n 27, 50.

39 Hwa-Jin Kim "Markets, Financial Institutions, and Corporate Governance: Perspectives From Germany" (1995) 26 Law \& Pol Int'l Bus 371, 392 ["Markets, Financial Institutions"].

40 "Convergence Versus Divergence" above n 37, 191. 


\section{B The German Code of Corporate Governance}

There have been several changes in German corporate governance in recent years. The most interesting change was the enactment of the German Code of Corporate Governance (the Code) in $2002 .^{41}$

In Germany, there have so far been no corporate scandals comparable to the Enron disaster in the United States. Although some scholars take the view that such scandals occurred, but were not published as broadly, ${ }^{42}$ the general opinion was that German corporate governance functioned well. ${ }^{43}$ Consequently, the reasons for the development of the German Code lay elsewhere.

Germany has decided that attracting international investors is the key to overcoming its economic crisis. Most of this money is located with institutional investors in the United States. ${ }^{44}$ The problem is, that these investors have trouble understanding Germany's system of corporate governance, because it is significantly different from the United States system. ${ }^{45}$ According to studies, there is a direct relationshp between investor confidence in capital markets and effective corporate governance. ${ }^{46}$ Some main criticisms of German corporate governance have been revealed. These include a lack of transparency; a lack of focus on shareholder interest; the two-tier board structure; and a lack of independence on supervisory boards and among auditors. ${ }^{47}$ The German Government decided to address such criticism and thereby increase the German capital market's attractiveness to international investors. ${ }^{48}$ The Code is a response to these main criticisms. ${ }^{49}$ It tries to make the German system more transparent and understandable. ${ }^{50}$

The German Code does not contain many new rules. It was designed after questionnaires had been sent to more than eighty experts and institutions. ${ }^{51}$ A large part simply reflects the statutory

41 "Germany: The German Corporate Governance Code", above n 33, 349.

42 An example mentioned is the circumstances of "EM TV", see Luca Enriques "Bad Apples, Bad Oranges: A Comment From Old Europe on Post-Enron Corporate Governance Reforms" (2003) 38 Wake For L Rev 911, 912-913

43 Wolff, above n 5, 129-130.

44 Wolff, above n 5, 128.

45 André, above n 6, 105.

46 "Convergence Versus Divergence", above n 37, 187.

47 "Germany: The German Corporate Governance Code", above n 33, 350.

48 Wolff, above n 5, 128.

49 Enriques, above n 42, 920-921.

50 Wolff, above 5, 128 .

51 Wolff, above n 5, 121. 
basis of German corporate law in order to summarise and explain the German system, especially codetermination and the dual board structure. The new rules are orientated to concerns of United States investors. They are divided into "recommendations"52 and "suggestions". 53 Recommendations are quasi-mandatory, because they demand companies to comply with, or explain non-compliance in their annual report. ${ }^{54}$ Non-compliance with suggestions does not have to be published. ${ }^{55}$ The most important provisions will be discussed in detail below.

\section{CORPORATE GOVERNANCE IN NEW ZEALAND}

Before evaluating the desirability of various regulatory schemes, the current corporate governance situation in New Zealand has to be analysed, focusing on recent developments and highlighting the question of whether New Zealand needs to reform its corporate governance regime.

\section{A The Situation in New Zealand Corporate Governance}

New Zealand's corporate regime is a mixture of statute, code and common law principles. ${ }^{56}$ The Companies Act 1993 provides the fundamental framework. Directors must act in the company's best interests and in good faith. ${ }^{57}$ It is the board's responsibility to manage the company's business and affairs. However, ultimate control is reserved for the shareholders. ${ }^{58}$

New Zealand's economy is dominated by small to medium-sized companies. ${ }^{59}$ Ninety-seven per cent of New Zealand firms fall into that category. ${ }^{60}$ Consequently, corporate governance in New Zealand must extend beyond large publicly listed companies. ${ }^{61}$ It is arguable that unlisted and particularly family-owned and co-operative businesses require different management principles, as there are no public shareholders affected. Owner-managers bear the costs of their own

52 These are signalled by the use of "shall".

53 Signalled by the use of "should" or "can".

54 Wolff, above n 5, 122.

55 "The German Corporate Governance Code", above n 33, 351.

56 Brynn Gilbertson and Andrew Brown "Corporate Governance In New Zealand" in The IFLR Guide to Corporate Governance 2002 (International Financial Law Review, London, 2002)

57 Companies Act 1993, s 131.

58 For a listing of the most important powers according to the Companies Act 1993, see Gilbertson and Brown, above n 56, 62-63.

59 Joseph Healy Corporate Governance and Wealth Creation in New Zealand (Dunmore Press Ltd, Palmerston North, 2003) 39.

60 Hon John Tamihere, Minister for Small Business "Inciting and Exciting Small Business" (Launch of the Small Business Day Series, Wellington, 13 February 2004).

61 Jane Diplock, Chairman, Securities Commission "Corporate Governance - Principles \& Public Policy" (Address to the School of Government, Victoria University of Wellington, 3 November 2003). 
incompetence. ${ }^{62}$ However, for a country like New Zealand, which has a significant number of these firms, it is important that these companies try to adhere to a high standard of principles in general, because, due to their predominance, they significantly influence New Zealand's corporate governance culture.

Many New Zealand companies have performed well in recent years. ${ }^{63}$ However, among the small number of underperforming firms were a comparatively high proportion of large companies. ${ }^{64}$ This has a significant influence on New Zealand's economy. The international reputation of a country's economy is dependant on its large companies. ${ }^{65}$ It is important to point out that the small size of an economy does not prevent its producing internationally successful large companies. ${ }^{66}$ Furthermore, internationally successful companies offer challenging careers for New Zealand management talents. ${ }^{67}$ This could keep such talent from going overseas.

\section{B Recent Developments in New Zealand}

There has been a vital discussion within New Zealand in recent years as to whether, and if so how, corporate governance should be altered. Many organisations and law firms have contributed their own reviews and principles. In May 2003, the New Zealand Securities Commission (the Commission) started a consultation process in order to identify levels of consensus and disagreement in New Zealand corporate governance. The Commission published a background paper and a questionnaire that could be filled out by any interested party. ${ }^{68}$ The background paper identified nine key areas, on which the discussion should focus:

- $\quad$ Ethical Conduct

- $\quad$ Board Composition and Performance

- Board Committees

- $\quad$ Reporting and Disclosure

- Remuneration

62 Healy, above n 59, 46.

63 Healy, above n 59, 33.

64 Healy, above n 59, 41.

65 Mark A Fox and Gordon R Walker "Evidence on the Corporate Governance of New Zealand Listed Companies" (1995) 8 Otago L R 317, 327-328.

66 Finnish Nokia or Swedish Ericsson provides good examples, despite their struggle in recent times.

67 Healy, above n 59, 52.

68 Securities Commission Corporate Governance in New Zealand: Consultation on Issues and Principles (Securities Commission, Wellington, 2003). 
- $\quad$ Risk Management

- $\quad$ Auditors

- Shareholder Relations

- $\quad$ Stakeholder Interests

The Commission issued its report Corporate Governance in New Zealand: Principles and Guidelines (the Principles) on 16 February 2004. ${ }^{69}$ The Commission issued nine principles, one for each key area mentioned above. However, these nine principles are very vague. They have already been criticised as "commonsense" and "self-evident". ${ }^{70}$ Hence, they provide little guidance for corporate governance. Even though companies are expected to report as to how they achieved each principle, ${ }^{71}$ this means little for ensuring good governance, due to their vague and broad wording. The guidelines issued for each principle provide more detailed guidance. However, companies are only expected to report against the principle, not against the guidelines. ${ }^{72}$ There are no mandatory requirements. Hence, the Principles are very weak. The Commission submitted the Principles to the Minister of Commerce. Whether this is the final word on New Zealand corporate governance is still unclear. $^{73}$

\section{Is There a Need for New Rules in New Zealand?}

The pivotal question is whether there is a need to issue new rules on corporate governance in New Zealand, since there have been no massive corporate scandals comparable to Enron.

However, in a world of globalised capital markets New Zealand cannot isolate itself. ${ }^{74}$ New Zealand is extremely dependent on foreign capital. ${ }^{75}$ There is international competition to attract

69 Securities Commission Corporate Governance in New Zealand: Principles and Guidelines (Securities Commission, Wellington 2004).

70 Paul Panckhurst "Guiding Rules For Directors Sit Well" (20 February 2004) The New Zealand Herald Auckland C3.

71 Corporate Governance in New Zealand, Principles and Guidelines, above n 69, 8.

72 Corporate Governance in New Zealand, Principles and Guidelines, above n 69, 8.

73 This paper was mainly written in March 2004 before the Principles were issued. Unfortunately, the Principles were issued a few months later than previously announced. There have been no further announcements as to whether the Ministry has any plans as to how to proceed with the Principles. This paper mainly takes the results of the consultation process into account.

74 Minter Ellison Rudd Watts "Corporate Governance White Paper" (Minter Ellison Rudd Watts, Wellington, 2003).

75 David Quigg "New Takeover Code to Enhance Shareholder Protection in New Zealand" (2001) 12 ICCLR 111, 112; In comparison, Australia - which has reacted to international developments and implemented new regulation on corporate governance - only depends half as much on international capital; Healy, above n 59, 29-49. 
foreign investors. ${ }^{76}$ Hence, it must view its corporate governance in an international context. Shareholders are mobile. Missing out on international developments therefore implies a double danger. Firstly, New Zealand loses ground in the global competition for international investors' money. ${ }^{77}$ A 2000 McKinsey study among investors found that three quarters of them thought that good corporate governance was as important as the financial performance when evaluating an investment. ${ }^{78}$ Losing investor confidence can not be afforded, given the fact that the poor performance of New Zealand companies in recent years already presents a problem in attracting investors. The average medium-large Australian company was almost 2.5 times more successful in the use of capital to develop growth than its New Zealand peer. ${ }^{79}$ Given the fact that Australia was even less successful than companies in the United States or United Kingdom, ${ }^{80}$ it is hard to see why an investor would consider investing in New Zealand. Secondly, New Zealand also risks losing domestic investors who might be attracted by international markets. A few numbers on the New Zealand stock market underline this danger. New Zealand's stock market almost stagnated in the last decade, while markets around the world were growing strongly. The NZSE had a market capitalisation of $\$ 43.3$ billion at the end of 1994 and was at $\$ 44$ billion by the end of $2001 .^{81} \mathrm{In}$ contrast, the market of the nearest neighbour, Australia, managed to grow from $\$ 282$ billion to $\$ 733$ billion during the same period. ${ }^{82}$ Of course there are some explanations for the relatively underdeveloped New Zealand stock market apart from those related to corporate governance. ${ }^{83}$ Nevertheless, this poor development might force domestic investors to invest in overseas markets.

The fact that New Zealand has to keep an eye on international developments does not mean that it has to blindly adopt whatever the economically strong nations do or international investors demand. ${ }^{84}$ Doing so would not help New Zealand in the long run. New Zealand has to take its own unique situation and requirements into account. New Zealand is neither comparable with the United

76 Mary E Kissane "Global Gadfiles: Applications and Implementations of US-Style Corporate Governance Abroad" (1997) 17 N Y J Int'l \& Comp L 621, 621.

77 Minter Ellison Rudd Watts, above n 74, 25.

78 McKinsey and Company <http://www.mckinsey.com> (last accessed 2 August 2005).

79 Healy, above n 59, 35 .

80 Healy, above n 59, 35 .

81 New Zealand Stock Exchange Annual Report for the Year Ended 31 June 2001 (New Zealand Stock Exchange, Wellington, 2001).

82 Healy, above n 59, 30-31.

83 For example, the agricultural sector is a significant part of New Zealand's economy and is not listed on the stock markets. Moreover, many large sectors have not been privatised in New Zealand (for example New Zealand Post, Transpower), which contribute to market growth in other countries; see Healy, above n 59, 32.

84 Minter Ellison Rudd Watts, above n 74, 1. 
States nor with Germany. New Zealand, as a smaller country, whose economy is still very much based on agricultural products, has unique requirements towards corporate governance. Therefore, it is important to critically analyse new regulative schemes in other countries in order to decide which rules are worth adapting.

\section{PROS AND CONS OF DIFFERENT RULES IN NEW ZEALAND}

This part deals with different questions surrounding the best approach for New Zealand corporate governance. The most important regulations in German and United States corporate governance will be discussed and weighed against the needs of New Zealand.

\section{A Strict Rules versus a Principles-Based Approach}

The most basic question is how to design the system in general. This question is of outstanding importance, for it significantly influences the decision of whether to implement a certain rule or not. In the case of adopting a strict rule-based approach that companies have to follow, one has to be much more careful to create generally applicable rules than when adopting non-mandatory principles.

There is a general distinction between highly prescriptive rules and a principles-based approach. ${ }^{85}$ One possibility for New Zealand is to follow the United States example and have a strict system of rules that every company has to follow. ${ }^{86}$ An alternative would be to follow the German (and the majority of other countries) ${ }^{87}$ example and install a principles-based approach. ${ }^{88} \mathrm{~A}$ third possibility is to take a middle road between the two.

The United States example of having mandatory and highly prescriptive rules has the significant advantage of preventing companies from circumventing unpleasant rules. ${ }^{89}$ Loopholes in regulations significantly contributed to the Enron disaster. Allowing companies to decide for themselves whether they will follow certain rules or not creates such loopholes in the first place. Mandatory rules avoid such risks. Apart from that, they provide for enforceability. The State can

85 Mark Walsh and Thomas Thesing "Extraterritorial Application of US Corporate Governance Standards in Europe" (2003) 14 ICCLR 165, 165.

86 Branson, above n 22, 1012

87 These other countries, importantly for New Zealand, include Australia and The United Kingdom; < http://www.kesteven.com.au/governance/codes.htm> (last accessed 27 July 2005).

88 There is a certain irony in the fact that a country like Germany (which is notorious for its mandatory statutory law) adopts a principles-based approach relying on market pressure to enforce compliance, while at the same time the United States (which usually uses self-regulation) implements strict mandatory rules; Wolff, above n 5, 120 .

89 William M Rees and Saleem Sheikh "Corporate Governance and Corporate Control: Self Regulation or Statutory Codification" (1992) 3 ICCLR 370, 371. 
thereby control compliance with important rules and to a certain extent guarantee good corporate governance standards. ${ }^{90}$ Furthermore, investors know the corporate governance structure of every company. Everyone has to comply with the same rules. It can be concluded that a highly prescriptive mandatory approach has the advantage of clarity.

However, highly prescriptive rules also have significant downsides. ${ }^{91}$ The most important disadvantage is the lack of flexibility. ${ }^{92}$ It is hard to believe that rules that concern the way a business is run will be equally applicable for every company. ${ }^{93}$ Sometimes companies might have fairly good reasons not to follow rules that are very important for other (or even the majority of) companies. $^{94}$

Nevertheless, a number of rules generally apply to each company and are useful to ensure good governance. ${ }^{95}$ In other words, there are several rules that should be applied to every company, provided there are no exceptional circumstances. A principles-based approach exactly serves that purpose. ${ }^{96}$ It sets up principles that generally should be complied with. However, when a company has a particular reason not to follow a rule, this approach leaves the company the flexibility to depart. ${ }^{97}$ The Commission's consultation process showed strong support for a principles-based approach in New Zealand. ${ }^{98}$

Notwithstanding the importance of flexibility, it is nevertheless important to have an enforcement tool. There is no sense in simply providing guidelines no company has to comply with. However, the New Zealand Principles do not impose any legal obligations on companies. ${ }^{99}$ Companies are simply expected to report on how they achieved the vague principles. The

90 Though no system of corporate governance will ever be capable of completely avoiding corporate scandals; Kim, above n 20, 252.

91 Branson, above n 22, 1013.

92 "Germany: The German Corporate Governance Code", above n 33, 351.

93 Cathy Quinn, Peter Rowe and Chris Linton "Where to go for Corporate Governance?" (Minter Ellison Rudd Watts, Auckland, 2003).

94 For example, without some flexibility in regard to who is considered to be an independent director, many qualified candidates with excellent knowledge of the company's business might automatically be disqualified; "The Review of the Role", above n 30, 250.

95 For examples, see the discussion of several rules below.

96 Stephen Franks "Corporate Governance Codes: Rules or Guidelines?" (2002) 4 CSLB 29, 31.

97 Minter Ellison Rudd Watts, above n 74, 3.

98 Corporate Governance in New Zealand: Principles and Guidelines, above n 69, 40.

99 Corporate Governance in New Zealand: Principles and Guidelines, above n 69, 6. 
guidelines, which include more detailed obligations, do not have to be reported on. ${ }^{100}$ It remains to be seen whether any further regulation is planned. The current version of the Principles provides a very weak system. The German approach is a "comply-or-explain" method of regulation. Each publicly held company has to either comply with the rules provided by the German Code or explain which rules have not been complied with. There is no direct enforcement. The idea behind the approach is that market pressure will force companies to comply. ${ }^{101}$ A company that does not sufficiently comply with the rules in the eyes of investors will face disinvestments and a fall in stock price. ${ }^{102}$ The question remains whether this is sufficient enforcement. This will to a large extent depend on what exactly a company has to explain. There has been a debate in Germany whether this also implies an obligation to explain why a company does not comply with these rules. The wording of section 161 of the Aktiengesetz leaves little room for discussion. There is no such obligation. ${ }^{103}$ This is different in Great Britain for example. The Combined Code demands companies to explain why they did not comply with a certain provision. ${ }^{104}$ The New Zealand regulations should also make explanation mandatory. ${ }^{105}$

Neither Germany nor the United States have implemented a mixed approach, combining strict mandatory rules with a set of non-mandatory principles. Though the German Code contains mandatory rules, these are not implemented by the Code, but simply repeat the existing German legal background. A mixed approach would enable the state to combine a set of very important mandatory rules with a set of principles for areas where there is less necessity for compliance or where no generally applicable rules are possible. Such an approach would combine the advantages of the United States' approach (clarity, enforceability) with those of the German approach (flexibility). The consultation process for the New Zealand principles showed some support for a mixed approach. ${ }^{106}$ However, such a concept is very complicated. Keeping in mind that one of the main reasons for adopting a code of corporate governance in New Zealand is to attract international investors, complication should be avoided.

It can be concluded that a principles-based approach is preferable in New Zealand. The small size of its economy combined with the fact that there are only a few large companies make a strict rule-base approach unnecessary. Flexibility is important, because the vast majority of New Zealand

100 Corporate Governance in New Zealand: Principles and Guidelines, above n 69, 8-10.

101 Wolff, above n 5, 125.

102 Quinn, Rowe and Linton, above n 93, 2.

103 "Germany: The German Corporate Governance Code", above n 33, 350.

104 Listing Rules (UK), r 12.43A.

105 Minter Ellison Rudd Watts, above n 74, 3.

106 Corporate Governance in New Zealand: Principles and Guidelines, above n 69, 40. 
companies might not be interested in attracting international investors. For them, a large set of mandatory rules would only result in unnecessary costs. Nevertheless, for ambitious and larger New Zealand companies it is important that New Zealand corporate governance is regarded as up to date with international standards. Therefore, a code of principles suits the New Zealand situation best. It should be designed as a comply-or-explain method of regulation, forcing a company also to explain why it did not comply with a certain principle. The current version of the New Zealand Principles is too weak and hence insufficient. The following paragraphs will analyse which principles should be applicable in New Zealand.

\section{B Code of Ethics for Senior Financial Executives}

The Act requires every company to disclose whether it has adopted a code of ethics for senior financial directors, and if not why not. ${ }^{107}$ It is the Act's only comply-or-explain provision. The German Code does not address the topic. In New Zealand the consultation process showed general support for a code of ethics. ${ }^{108}$ It can be said that such a code of best practice for the board should be implemented. However, one should not expect too much of it. Implementing such a code by itself does not mean the company has addressed ethical topics sufficiently. ${ }^{109}$ Even Enron had such a code. ${ }^{110}$ The pivotal point is that waivers of or changes in the code have to be disclosed and thereby are made public. Waivers from Enron's code of ethics enabled Chief Financial Officer Andrew Fastow to receive generous fees from his self-designed "special purpose entities". ${ }^{111}$ New Zealand should include a provision that waivers from the code need to be published immediately to inform shareholders.

\section{Auditors}

Auditing from outside companies is key to corporate control. Though inside monitoring through independent directors is important, outside monitoring through independent auditors is crucial for obtaining an independent expert opinion. Both in Germany and in the United States new rules concerning auditors have been implemented.

\section{Prohibition of consulting services?}

The Act focuses quite strongly on auditors and accounting. Beside the enactment of the new accounting oversight board (see below) the Act also implements a number of new obligations and prohibitions concerning auditors. Most significantly, the Act prohibits an auditing company from

107 Hamilton, above n 3, 63.

108 Corporate Governance in New Zealand: Principles and Guidelines, above n 69, 42.

109 Minter Ellison Rudd Watts, above n 74, 13.

110 Branson, above n 22, 1008.

111 Branson, above n 22, 1008. 
providing certain consulting services to the same client. ${ }^{12}$ Furthermore, an accounting firm is prohibited from providing audit services to any company whose CEO, CFO, chief accounting officer or person of similar responsibility worked for the accounting firm in the last year. ${ }^{113}$ Lastly, the Act requires rotating the lead audit partner at least every five years. ${ }^{114}$

The German Code is less strict. The supervisory board by law is responsible for choosing the auditor and agreeing on its fees. ${ }^{115}$ Furthermore, the law requires the auditor to take part in all supervisory board meetings concerning financial statements. ${ }^{116}$ The Code only implements two new obligations in respect to auditors. The auditor has to declare whether any, and then which, relations to the company or its directors exist that could influence its independence prior to its selection. ${ }^{117}$ The Code particularly demands disclosure, not just of any recent or actual (especially consulting) contracts, but also any contracts for the following year. If such conflicts of interest arise after the auditor has been engaged, it has to inform the supervisory board immediately. The same obligation arises if the auditor discovers any facts that could be relevant to the supervisory board's functions, especially evidence of potential breach of director's duties. ${ }^{118}$

The question arises, whether prohibiting the provision of consulting services by auditors makes sense in New Zealand. The United States' prohibition is designed to improve auditor independence. ${ }^{119}$ In 2000, Enron paid its auditor Arthur Andersen US\$25 million in auditing fees, but US\$27 million in consulting fees. ${ }^{120}$ Such circumstances provide an incentive for the auditor to avoid risking the lucrative relationship to its client, thus undermining its independence. ${ }^{121}$ However, there are two main arguments against the prohibition of the provision of consulting services. Firstly, these services provide the accountant with the necessary background information and enable it to understand its client's business. This is helpful for providing proper auditing services. ${ }^{122}$ Furthermore, there would be additional costs, because this information would have to be generated

112 Section 201 of the Act; Hamilton, above n 3, 58.

113 Branson, above n 22, 1009.

11415 USC $§ 78 \mathrm{j}-1$ (2002); Hamilton, above n 3, 58.

115 German Code, s 7.2.2.

116 German Code, s 7.2.4.

117 German Code, s 7.2.1.

118 German Code, s 7.2.3.

119 Hamilton, above n 3, 58.

120 Branson, above n 22, 1010.

121 Kim, above n 20, 244.

122 Kim, above n 20, 243-244. 
by the auditor. ${ }^{123}$ Secondly, consulting services provide additional income for accountants and thereby increase their independence. Notwithstanding these concerns, prohibiting the provision of consulting services is a necessary step. Otherwise, conflicts of interest are inevitable. An auditor, economically dependent on the profits generated from performing consulting services for a client, is unlikely to paint an accurate picture of its financial situation in the case of crisis. ${ }^{124}$ Financial accounting always involves a degree of inaccuracy. ${ }^{125}$ Given that, there has to be a measure to avoid immoderate interdependence. The risk of losing the accounting job is financial incentive enough to issue favourable reports, ${ }^{126}$ but that risk is even larger when there is other business at stake.

However, the question is whether the New Zealand situation requires such a drastic step. Opinion on this topic was divided among participants of the New Zealand consultation process. There was a strong view that certain services that could potentially undermine the auditor's impartiality should be forbidden. ${ }^{127}$ It has to be kept in mind that the New Zealand market is small. Having only a limited number of auditors, a general prohibition of non-audit services is difficult. Furthermore, the additional costs involved provide a bigger burden, because New Zealand companies are smaller than their United States counterparts. Therefore, a general prohibition of the provision of consulting services by auditors overshoots the mark in New Zealand. Prohibiting only certain services is difficult, because potentially every other service undermines the auditor's impartiality, due to the fees paid. The different services mentioned in the consultation process already indicate that it will be hard to decide which services should be forbidden. Since the arising conflicts of interest are nevertheless critical in the important field of auditing, the German rules could be adopted. The company has to publish existing contracts with the auditor. This suggestion gained almost unanimous support among participants in the New Zealand consultation process. ${ }^{128}$ The publication should also include future contracts, because these provide an equal incentive to be less objective as recent contracts. An alternative would be a financial limit, allowing consultation fees to be only a certain percentage of the auditing fees. However, the majority of New Zealand professionals oppose fixed levels on the grounds that they are too inflexible. ${ }^{129}$

123 Kim, above n 20, 235, 244.

124 Kim, above n 20, 235, 244.

125 Branson, above n 22, 1004.

126 The audit fees Enron paid were US\$25 million.

127 Examples mentioned included tax services, risk management, executive recruitment, and strategic planning; Corporate Governance in New Zealand, Principles and Guidelines above n 69, 66.

128 Corporate Governance in New Zealand: Principles and Guidelines, above n 69, 66.

129 Corporate Governance in New Zealand: Principles and Guidelines, above n 69, 66-67. 


\section{Rotation of auditors?}

The second question is whether New Zealand should implement any rules as to the rotation of auditors. German law does not prescribe anything. In the United States, the Act requires rotating the lead audit partner at least every five years. ${ }^{130}$ This rule is designed to avoid auditor and company from becoming too familiar. The question remains whether this goes far enough. United States legislation stopped short of requiring mandatory rotation of the audit company itself. ${ }^{131}$

Despite the fact that the New Zealand Securities Commission sees it as a good balance between cost losses and independency gains, ${ }^{132}$ the efficiency of simply changing the lead audit partner can be doubted. While there is a danger in the audit partner and the company becoming too close, ${ }^{133}$ there are also positive factors in a long relationship. Firstly, an auditor that has known a company's performance (and its books) for years is more likely to detect irregularities. Secondly, a new lead audit partner would have to become acquainted, which results in unnecessary costs. A real improvement would be to make the rotation of the audit firm mandatory. This approach serves the purpose better and would at least justify the dedication of time and money connected with changing the auditor. A different partner in the same auditor firm is unlikely to criticise a colleague anyway. Therefore, there either should be a need to change the entire audit company or no obligation at all. Due to the limited number of audit companies and qualified auditors available in New Zealand, the latter seems preferable. ${ }^{134}$

\section{Board Composition}

One of the most discussed questions worldwide is the question of the composition of the board of directors. Since the board is responsible for monitoring management and making critical decisions, it has a crucial function in corporate governance. ${ }^{135}$ Consequently, assigning the board is one of the most critical decisions in order to secure good governance. The question is whether there is a generally applicable recipe for the composition of the ideal board.

130 Hamilton, above n 3, 58.

131 Branson, above n 22, 1009.

132 The great majority of participants in the consultation process agreed on this point; Corporate Governance in New Zealand: Principles and Guidelines, above n 69, 29/65-66.

133 Minter Ellison Rudd Watts, above n 74, 19.

134 The majority of participants in the consultation process also pointed out the small number of qualified auditors in New Zealand and opposed mandatory rotation of the audit firm; Corporate Governance in New Zealand: Principles and Guidelines, above n 69, 65

135 Corporate Governance in New Zealand: Consultation on Issues and Principles, above n 68. 


\section{Independent directors}

The standard answer in recent years has been to focus on independent directors. ${ }^{136}$ However, there has been some discussion about when a director can be said to be independent. A variety of definitions have been offered. ${ }^{137}$ There are some generally applicable criteria for non-independence. An executive director cannot be considered independent. ${ }^{138}$ Other factors regularly mentioned as negating independence include recent employment by the company or engagement as an advisor for the company, being affiliated with its customers or suppliers or being related to such people, and being a major shareholder. ${ }^{139}$ Ideally, an independent director is free from any relationship with management and any other business interests in the company that could possibly interfere with the exercise of an independent judgment. ${ }^{140}$ However, independence is a matter of degree. With time, a director that was initially considered independent will slowly become dependent, due to involvement in the company. ${ }^{141}$

In the United States, the Act requires every company to have an audit committee composed solely of independent directors. ${ }^{142}$ The Act also defines what constitutes an independent director. ${ }^{143}$ The German Code recommends that the supervisory board always has members who have the knowledge, abilities and experience required and who are "sufficiently independent". 144 There should not be more than two former members of the management board. ${ }^{145}$ Furthermore, members of the supervisory board should not be directors or advisors for competitors. ${ }^{146}$ German law prohibits members from pursuing personal interests in relation to the company. ${ }^{147}$ Any contracts

136 Jacques Delga "Corporate Governance and the Independent Director: The Independent Director in France" (2004) 15 ICCLR 1, 1; Harvey Gelb "Corporate Governance Guidelines - A Delaware Response" (2001) 1 WYLR 523, 550 .

137 Saleem Sheikh "Non-Executive Directors: Self-Regulation or Codification" (2002) 23 Comp Law 296, 296297; Gelb, above n 136, 527-528.

138 Delga, above n 136, 2.

139 Sheikh, above n 137, 301; these key elements also had strong support in the Commission's consultation process; Corporate Governance in New Zealand: Principles and Guidelines, above n 69, 45.

140 Rees and Sheikh, above n 89, 373

141 Gelb, above n 136, 552

142 Hamilton, above n 3, 59-60.

143 Lawrence E Mitchell "The Sarbanes-Oxley Act and the Reinvention of Corporate Governance?" (2003) 48 Vill L Rev 1189, 1198.

144 German Code, s 5.4.1.

145 German Code, s 5.4.2.

146 German Code, s 5.4.2.

147 German Code, s 5.5.1. 
between the company and supervisory board members need to be approved by the board. ${ }^{148}$ Members should also report conflicts of interest to the board, ${ }^{149}$ which should publish these and their treatment to the general meeting. 150

Divergence in the German and the United States models partly results from the German system of co-determination, which requires German companies to have members on the supervisory board who are generally not considered independent according to United States standards. ${ }^{151}$ However, it is significant that the German Code does not require any real independence from supervisory board members, while the Act focuses quite heavily on them. ${ }^{152}$ The question arises as to whether requiring independent directors makes sense at all and particularly in New Zealand. The NZSE Listing Rules only require listed companies to have a minimum of three directors, including two ordinary New Zealand residents. ${ }^{153}$ They recommend a minimum of two or, if there are eight or more directors, one-third, independent directors. ${ }^{154}$

The idea behind requiring independent directors is that they improve corporate governance because they do not have their own interests at stake. This shall enable them to act in the company's best interest when making a decision without any conflicts of interest, ${ }^{155}$ and to monitor management effectively. ${ }^{156}$ Furthermore, they might bring fresh ideas into the company. ${ }^{157}$ Hence, they can be important for counterbalancing management's power. ${ }^{158}$

However, independent directors are also subject to criticism. ${ }^{159}$ Firstly, it is questionable whether independent directors devote enough time to their directorship. ${ }^{160}$ Secondly, they might not

148 German Code, s 5.5.4.

149 German Code, s 5.5.2.

150 German Code, s 5.5.3.

151 Exceptions are union representatives. However, mostly the members of the supervisory board elected by the employees are employees of the company themselves.

152 Enriques, above n 42, 921.

153 NZX Listing Rules, r 3.3.1 (a) and (b).

154 NZX Listing Rules, 4 3.3.1 (c).

155 Rees and Sheikh, above n 89, 373.

156 Mark J Loewenstein "The SEC and the Future of Corporate Governance" (1994) 45 Ala L Rev 783, 784785.

157 Gelb, above n 136, 525.

158 Sheikh, above n 137, 298.

159 Sheikh, above n 137, 297-298.

160 Rees and Sheikh, above n 89, 373. 
really know the company's business, ${ }^{161}$ and thus have to rely on the information provided to them by management. ${ }^{162}$ Because of their limited knowledge, they might be unable or reluctant to ask the right questions in board meetings. ${ }^{163}$ A powerful CEO might intensify this effect. On the other hand, being independent does not mean that directors are not qualified, they could for example be financial experts or academics. It is crucial to choose qualified candidates. Good governance is primarily a question of substance and not of form. ${ }^{164}$ In any case, it is important for independent directors to meet without management and non-independent directors from time to time in order to discuss issues without negative interference. ${ }^{165}$ The German Code contains such a provision concerning the members of the supervisory board. ${ }^{166}$ Unlike common practice, they shall meet without the presence of the management board in appropriate cases.

In New Zealand another problem occurs. Due to the country's small size and relative isolation, the number of qualified candidates is limited. ${ }^{167}$ It is estimated that Australia's new rules will force them to find 10,000 new directors to meet the independence requirements. ${ }^{168}$ While United States and German companies can easily find a large number of potential independent directors, a New Zealand company might find this much more troublesome. Moreover, due to their smaller size, many New Zealand companies also require a board that is more involved in management, is knowledgeable in matters relating to the company, and is able to support the company as it grows. ${ }^{169}$ Having independent directors alone does not improve corporate governance. ${ }^{170}$ It could be argued that the most important thing is to have the best directors on board, regardless of whether they are considered independent or not. ${ }^{171}$ Nevertheless, the idea of having independent directors is

161 Minter Ellison Rudd Watts, above n 74, 14.

162 Sheikh, above n 137, 298.

163 Rees and Sheikh, above n 89, 373.

164 Gelb, above n 137, 526.

165 Minter Ellison Rudd Watts, above n 74, 12; this also provides an example of a situation where such a meeting might have resulted in avoiding a fraud by a senior executive.

166 German Code, s 3.6.

167 This fact is also pointed out by the Securities Commission; Corporate Governance in New Zealand: Principles and Guidelines, above n 69, 17.

168 Quinn, Rowe and Linton, above n 93, 2.

169 Quinn, Rowe and Linton, above n 93, 2.

170 Delga, above n 136, 5 .

171 The danger of missing out on some of the best people in case of having a strict definition has also been pointed out by some respondents in the consultation process; Corporate Governance in New Zealand: Principles and Guidelines, above n 69, 46. 
favourable. Chosen well, they can perfectly complete the board. ${ }^{172}$ Here the flexibility of a principles-based approach pays. Companies have to be able to make exceptions for directors that are not independent in the strict sense of the definition, but where there is nevertheless good reason to nominate them as a director. ${ }^{173}$ Due to the limited number of potential candidates in New Zealand the suggestion that one-third of the directors be independent seems reasonable.

Some scholars go a step further and suggest the implementation of public directors. ${ }^{174}$ This is an interesting idea. However, it is not suitable for New Zealand, as it would be a completely new approach and might repel international investors rather than improve their confidence in a modern New Zealand system of corporate governance.

The optimal board size is disputed. Large boards are said to be less effective. ${ }^{175}$ This is true in the case of extremely large boards. They also provide an opportunity for single directors to hide behind others and not become personally involved in discussions. However, though smaller boards may be more harmonious, the danger is that such harmony comes at the cost of sufficient depth. ${ }^{176}$ It seems safe to assume that there is no general solution. The optimal size of the board will vary from company to company, depending on its size, business and state of development. ${ }^{177}$ It is much more important to create a good mix of skills and knowledge that suits the company's particular needs. To these considerations the question of board size is secondary. ${ }^{178}$ Hence, there should not be any regulation regarding the size of the board. Requiring a certain number of independent directors will be sufficient.

\section{Separation of chairman and CEO}

There is a wide agreement that the chairman of the board and the CEO should not be the same person. ${ }^{179}$ This is important, because the CEO already has significant power by definition. The chairman also has a fundamental role within the corporate system, including the overall

172 They can also have an important function in smaller companies by bringing experience to the board; Sheikh, above n 137, 299.

173 "The Review of the Role", above n 30, 250-251.

174 Rees and Sheikh, above n 89, 373.

175 Janis Sarra "Corporate Governance in Global Capital Markets, Canadian and International Developments" (2002) 76 Tulane L Rev 1691, 1724 ["Corporate in Global Capital Markets, Canadian and International Developments"].

176 Franks, above n 96, 30.

177 Corporate Governance In New Zealand: Consultation On Issues And Principles, above n 68.

178 Franks, above n 96, 30.

179 Corporate Governance in New Zealand: Principles and Guidelines, above n 69, 46-47. 
responsibility for the board. ${ }^{180}$ Combining the two positions results in an undesirable concentration of power. ${ }^{181}$ There is no counterpart for the CEO. Given the fact that the chairman sets the board's agenda and chairs all meetings, they have a great influence on the way the board works. ${ }^{182}$ Hence, the positions should be separate. Unlike in the United States, ${ }^{183}$ where the chairman and CEO are frequently the same person, ${ }^{184}$ the separation of both positions already is the norm in New Zealand. ${ }^{185}$ Nevertheless, there should be clarification of this in the New Zealand principles.

\section{Limitation in the number of board memberships?}

With the increasing complexity of today's economy, it becomes more and more important that directors allow sufficient time to effectively fulfil their roles. Effective monitoring requires more than simply reading the board papers and attending meetings. ${ }^{186}$ The German Code addresses the problem by recommending that a person should not be a member of more than five supervisory boards. ${ }^{187}$ Furthermore, it should be reported in the supervisory board's annual report if a member attended less than half of the board's meetings. ${ }^{188}$ It is arguable that there will regularly be a correlation between the time a director devotes to the job and the level and quality of control over management. In Germany, in the past, it was not unusual for people to be members of more than 10 companies' supervisory boards. ${ }^{189}$ Keeping in mind that most of these individuals have a full time position elsewhere, for example as an executive or lawyer, the question arises whether their function on the board exceeds pure representation. The monitoring of the executives is very important and requires the devotion of a substantial amount of time. ${ }^{190}$ Therefore, a limitation in the number of directorships makes sense, despite the limited number of potential directors in New Zealand, and in spite of the fear that an increased demand in time will result in increasing directors' fees. ${ }^{191}$ However, one might consider allowing a larger maximum number of memberships to take account

180 Rees and Sheikh, above n 89, 373.

181 Rees and Sheikh, above n 89, 373.

182 For an overview of all powers and responsibilities of the chairman, see Minter Ellison Rudd Watts, above $\mathrm{n}$ 74,9 .

183 In the United States only 20 per cent of companies separate the positions; Burbidge, above n $25,649$.

184 Minter Ellison Rudd Watts, above n 74, 17.

185 Quinn, Rowe and Linton, above n 93, 1.

186 Minter Ellison Rudd Watts, above n 94, 6.

187 German law allows membership in up to ten: German Code, s 5.4.3.

188 German Code, s 5.4.6.

189 "The Review of the Role", above n 30, 251.

190 Sheikh, above n 137, 298.

191 Minter Ellison Rudd Watts, above n 74, 6. 
of the fact that there is a large number of small companies in New Zealand, where directorship might not be as time consuming as in larger corporations.

Apart from that, some have suggested limiting the time an independent director may serve on the board of a company. ${ }^{192}$ While the independence of a director might vanish after several years on the company's board, ${ }^{193}$ such a fixed provision should not be implemented in New Zealand. The director gains knowledge and experience while on the board. It seems more important that each company generally assess its board composition from time to time, because a company might require a different mix of skills in different stages of its development. ${ }^{194}$ Therefore, it does not help to adopt any generally applicable rules.

The German Code also recommends an age limit for members. ${ }^{195}$ This provision does not make sense, for the focus should be on the abilities of a candidate rather than on his or her age.

\section{E Board Committees}

The setting up of special board committees has been discussed widely in recent times. Looking at the regulations and codes issued around the globe, it can be concluded that the establishment of an audit committee is regarded as essential in improving supervision.

\section{Audit committee}

Both the Act and the German Code address the issue of audit committees. However, the extent to which they do so differs significantly.

In the United States, the Act requires every company to have an audit committee composed solely of independent directors. ${ }^{196}$ Furthermore, the audit committee has to contain at least one "financial expert". 197 Prior to the Act, there had not been any legal provisions addressing an audit committee's duties. ${ }^{198}$ The audit committee is responsible for hiring the accounting firm and will receive its reports. ${ }^{199}$ In other words, the Act shifts the main audit responsibilities away from the board towards an entity that consists solely of independent directors, including a financial expert.

192 Sheikh, above n 137, 302.

193 Gelb, above n 136, 552.

194 Minter Ellison Rudd Watts, above n 74, 11.

195 German Code, s 5.1.2.

196 Sarbanes-Oxley Act, above n 1, s 301.

197 Sarbanes-Oxley Act, above n 1, s 407.

198 Kim, above n 20, 243.

199 Hamilton, above n 3, 59. 
The German Code is less specific. ${ }^{200}$ It states that the supervisory board shall form expert committees depending on the specific structure of the company in order to improve its efficiency. ${ }^{201}$ It requires the appointment of an audit committee. ${ }^{202}$ The only other determination the Code makes towards the audit committee is that its chairman should be neither the chairman of the supervisory board, ${ }^{203}$ nor a former member of the management board. ${ }^{204}$

The German approach must be seen as an attempt to please international investors. There is not much logic in having an audit committee under the German system. ${ }^{205}$ Monitoring the management board is already the supervisory board's key function. A separate audit committee might only make sense when it is supposed to overcome the fact that, due to co-determination, the supervisory board cannot be comprised solely of independent directors. Such an approach could only have made sense if the members of the audit committee would have to be independent. However, this is not the case. The German regulation therefore is half-hearted and does not improve corporate governance. It would have made more sense to address criticism towards the supervisory board.

The United States approach is much more interesting. The intention is to detect any failure in a company's accounting. ${ }^{206}$ It had been realised in the United States that one of the reasons that made scandals such as Enron possible was a lack of efficient control of executive directors' powers. If independent directors with financial expertise, unbothered by management or directors with personal interests cannot prevent misleading accounting, who else can? The idea behind the rule is good. More independence inside a monitoring unit is hardly possible. However, it has been pointed out that membership of an audit committee is almost a "full time job". ${ }^{207}$ This is likely to result in increased costs. On the other hand, it should not be too time-consuming in New Zealand companies, due to their small size, if the audit committee focuses on its main responsibility of monitoring. Besides, directors generally have to realise that their presence on companies' boards has a purpose and involves some work, rather than being prestigious and an easy way to earn some extra money. A special burden rests on the committee's financial expert. They would be considered the person most responsible for detecting any irregularities. This should result in improved diligence compared to

200 Walsh and Thesing, above $\mathrm{n} 85,166$

201 German Code, s 5.3.1.

202 German Code, s 5.3.2.

203 German Code, s 5.2.

204 German Code, s 5.3.2.

205 Walsh and Thesing, above n 85, 167.

206 Kim, above n 20, 242-243.

207 Branson, above n 22, 1006. 
regular directors. ${ }^{208}$ The question is, whether bearing such responsibility will require increased remuneration. The expert will be the first one to be blamed in case of failure. However, such increased costs should be considered reasonable in the achieving of reliable monitoring.

New Zealand should consider adopting the main United States rule as a principle. ${ }^{209}$ Currently there are no mandatory requirements for board committees. ${ }^{210}$ However, audit committees are increasingly common practice in New Zealand, ${ }^{211}$ and they have become an international standard. ${ }^{212}$ A separate audit committee can more effectively monitor the board than the board itself, because of many board members' involvement in executive decisions. This will improve corporate control when the audit committee comprises of qualified candidates. It is a good idea to separate the role of the board and the committee's chairman in order to have another powerful person in the company. ${ }^{213}$ The chairman of the board is often too involved with management. An independent director should therefore be chairman of the audit committee. ${ }^{214}$ However, one thing should not be overlooked in the current enthusiasm for audit committees: the installation of an audit committee does not absolve the full board of responsibility. ${ }^{215}$ It is important to point that out in the principles. ${ }^{216}$ Finally, a financial expert should not expressly be required in New Zealand, due to limited financial and personal resources, though it generally makes sense to have people with financial expertise on the audit committee. Larger companies with international ambition should nevertheless think about appointing such an expert. However, there should not be a requirement to name a person as financial expert.

\section{A separate second board as the more logical approach?}

An interesting question arising from the implementation of audit committees is whether establishing a second, independent board would not be the more logical approach.

208 Mitchell, above n 143, 1199.

209 The consultation process showed strong support for such a requirement: Corporate Governance in New Zealand: Principles and Guidelines, above n 69, 52.

210 Gilbertson and Brown, above n 56, 54.

211 Corporate Governance in New Zealand: Principles and Guidelines, above n 69, 20.

212 Minter Ellison Rudd Watts, above n 74, 18.

213 Minter Ellison Rudd Watts, above n 74, 18.

214 The Commission has suggested this as a guideline: Corporate Governance in New Zealand: Principles and Guidelines, above n 69, 19.

215 Minter Ellison Rudd Watts, above n 74, 19.

216 This Commission has done that: Corporate Governance in New Zealand: Principles and Guidelines, above n $69,19$. 
The purpose of the audit committee is to monitor management. Having an audit committee is seen as necessary, because the board of directors (whose job monitoring usually is) cannot be trusted to monitor effectively due to the involvement of executives on the board. The arising conflict of interest is obvious. Executive directors monitor themselves. The idea of an audit committee comprised of independent directors to overcome this difficulty is good. However, the members of the audit committee would be much more independent if they were not members of the board of directors at all. It is much more likely that they would criticise the decisions of a board they are not involved in than decisions they took part in themselves.

The installation of a separate second board has not been discussed in the United States. In theory, a second independent board has some significant advantages. ${ }^{217}$ The idea is to approve and control management's decisions through a group without a vested interest. ${ }^{218}$ This should improve shareholder protection. ${ }^{219}$ The rigid constitutional separation makes the independent directors' roles much clearer. ${ }^{220}$

In practice German supervisory boards have some disadvantages. The first one is their size, which makes decisions complicated. ${ }^{221}$ The average German supervisory board contains 18 members. ${ }^{222}$ However, this is mainly the result of co-determination. This should be avoided when implementing a second board elsewhere. The main criticism is the lack of information the supervisory board has. Since it is independent, it relies on the management board to supply information. However, in practice this information does not flow as required, ${ }^{223}$ resulting in a lack of material available to monitor the board of directors efficiently. ${ }^{224}$ This problem could be addressed by having one supervisory board member regularly attending board meetings as an observer.

It can be concluded that a separate second board could in fact be a reasonable alternative and a consequent development of the requirement of having an audit committee comprised of independent directors. The cost argument lacks proof. Supervisory board members are not as highly paid as

217 Yavasi, above n 27, 49.

218 Chantayan, above n 26, 439.

219 Chantayan, above n 26, 439.

220 Burbidge, above n 25, 652 .

221 "Corporate Governance In Global Capital Markets, Canadian And International Developments", above n $175,1724$.

222 Burbidge, above n 25, 652.

223 Chantayan, above n 26, 441 .

224 "The Review of the Role", above n 30, 269. 
management board directors. ${ }^{225}$ If one takes into account that fewer (independent) directors are needed on the first board as a consequence, there might in fact be no additional cost. Nevertheless, this approach is not favourable for New Zealand at this point in time. Given the fact that international investors are repelled by a system unknown to them, New Zealand would be better to implement an audit committee.

\section{Other committees?}

The Act does not prescribe any other committees. However, at least a nomination and a remuneration committee are common in United States companies. ${ }^{226}$ Some scholars demand making at least a nomination committee mandatory in order to control the CEO's power to influence directors' nominations. ${ }^{227}$ In the German Code, forming other committees is suggested but without an obligation to explain in the case of non-compliance, but it is stated that the supervisory board can delegate certain topics to committees and empower them to make decisions instead of the whole board. 228

New Zealand's principles should not require the installation of committees other than audit committees, though several New Zealand companies in fact already have them. ${ }^{229}$ This might make sense for larger companies, but the majority of New Zealand companies are small. ${ }^{230}$ There is not much sense in requiring a company with three directors to have a separate nomination or remuneration committee. Instead, there should be a provision that an executive director should not attend a meeting discussing his or her own remuneration. ${ }^{231}$ The biggest problem with committees is that they provide an incentive for non-members to rely on the committee to do all the work. While committees might save the full board some time, it should never be forgotten that ultimately the full board is responsible for all decisions. ${ }^{232}$

225 "The Review of the Role", above n 30, 252.

226 Burbidge, above n 25, 645-646.

227 The CEO therefore shall be excluded from membership on the nomination committee: Branson, above $\mathrm{n} 22$, 1014.

228 German Code, s 5.3.3.

229 Minter Ellison Rudd Watts, above n 74, 10.

230 This was also pointed out by some respondents in the Commission's consultation process: Corporate Governance in New Zealand: Principles and Guidelines, above n 69, 53

231 Minter Ellison Rudd Watts, above n 74, 8.

232 Minter Ellison Rudd Watts, above n 74, 11. 


\section{F Reporting and Disclosure}

Transparent reporting and disclosure is vital for good corporate governance. These are the principal means by which directors and executives are accountable to shareholders. ${ }^{233}$

1 Real-time disclosure and off-balance sheet accounting

German law requires a corporation to disclose any non-public facts which could significantly influence its stock price. In the United States, the Act requires "real time" disclosure in "plain English" on a "rapid and current base", which is supposed to mean within two business days of a trade. $^{234}$ Moreover, the company also has to post the trade on its website within a further three days. ${ }^{235}$ The requirement for reporting only at the end of the year was one of the loopholes that enabled Enron's CEO, Kenneth Lay to sell shares back to the company without immediate disclosure. ${ }^{236}$ Furthermore, all off-balance sheet transactions that may have a material effect on the company's financial condition have to be disclosed. 237 Off-balance sheet accounts were one of the major problems in Enron's collapse. Enron's Chief Financial Officer (CFO), Andrew Fastow, had hidden millions of dollars in debts in off-balance-sheet transactions, using hundreds of so-called "special purpose entities". ${ }^{238}$ New Zealand has implemented "continuous disclosure" for listed companies, ${ }^{239}$ so the problem of immediately releasing material information has already been addressed. ${ }^{240}$

\section{Quarterly reporting?}

United States and German laws on accounting requirements differ significantly. Traditionally, United States legislation was much stricter. The reason for these differences lay in the different structure of shareholding. Since German banks and insurers, as major shareholders, are well informed about the companies' situation through their "managers" on the boards, they do not require the same amount of information small United States investors depend on. United States law requires companies to provide quarterly reports. This helps in keeping up-to-date on the state of the

233 Greater transparency was one of the major goals of the German Code: "Germany: The German Corporate Governance Code", above n 33, 352.

234 Hamilton, above n 3, 64.

235 Branson, above n 22, 1008.

236 Branson, above n 22, 1008.

237 Kim, above n 20, 248.

238 For an extended overview, see Branson, above n 22, 1000-1002.

239 NZX Listing Rules, r 10.1.1.

240 The consultation process showed that a majority of respondents regard the current New Zealand system as sufficient: Corporate Governance in New Zealand: Principles and Guidelines, above n 69, 56. 
company. German law only requires companies to issue an annual report, prepared by the managing board and controlled both by the supervisory board and the auditor. The German Code recommends the provision of interim reports to keep shareholders informed during the year. ${ }^{241}$ All reports shall be prepared using Generally Accepted Accounting Practice (GAAP). Moreover, reports shall be publicly accessible: annual reports within 90 days of the end of the financial year and interim reports within 45 days after the end of the reporting period. ${ }^{242}$

In other words, the German Code adopted more frequent reporting from the United States. However, this should not be copied by New Zealand. ${ }^{243}$ Quarterly reporting is extremely costly. For smaller companies, of which New Zealand has a large number, such a requirement does not seem to be of much use. Annual reporting seems sufficient in New Zealand, especially because continuous disclosure requirements keep shareholders updated in the meantime. If larger companies are eager to report more frequently they are free to do so, in order to comply with the expectations of foreign investors, for example.

Few New Zealand companies provide meaningful details on their corporate governance policy to their shareholders. ${ }^{244}$ Since good governance also includes information about governance itself, there should be a provision requiring companies to disclose their corporate governance policy. As with other reports, the companies should be required to use modern communication systems in order to make such information available to all shareholders as well as potential investors. The internet provides a cost effective method to keep investors updated at any time. ${ }^{245}$

\section{CEO and CFO certification requirements?}

The Act imposes certification obligations on the company's executives. The CEO as well as the $\mathrm{CFO}$ has to certify in each report that the report does not contain any untrue statements and presents a true and fair view of the company's financial situation. ${ }^{246}$ Previously, it was enough if reports of a United States company were compliant with GAAP. ${ }^{247}$ Aligning United States law with the law in

241 German Code, s 7.1.1.

242 German Code, s 7.1.2.

243 The majority of respondents in the consultation process had the same opinion; Corporate Governance in New Zealand: Principles and Guidelines, above n 69, 57.

244 Healy, above n 59, 49.

245 The German Code recommends the use of the internet for various purposes to improve communication with shareholders (see s 6.6 of the German Code).

246 Hamilton, above n 3, 60.

247 Mitchell, above n 143, 1201. 
most other English speaking countries, the report now has to go beyond the requirements of GAAP and represent a true and fair view. ${ }^{248}$

Apart from that, the CEO and CFO have to ensure and certify that internal corporate controls are adequate and in place. ${ }^{249}$ They are responsible for designing internal controls that ensure the flow of financial information to them. These controls have to be checked within 90 days prior to certification. ${ }^{250}$ Before the Act, the law did not require internal controls. ${ }^{251}$ There are no comparable provisions in the German law or Code. ${ }^{252}$

The United States rules have been criticised as being too harsh. Critics have pointed out the significant stress these provisions put on executives. Substantial penalties, including imprisonment for up to 20 years, are imposed for filing a wrong statement. ${ }^{253}$ In relation to the relatively small number of incapable directors, the regulation has been described as inefficient. ${ }^{254}$ Branson argues that less than one per cent might be affected. ${ }^{255}$ However, it is strange to criticise a punishment because of rare occurrence. The problem is that the few cases in which something went wrong might be exceptions, but thousands of people were affected. All the Enron employees who lost their jobs as well as pension funds should not be lost sight of. Besides, the majority of directors have nothing to fear. They can easily certify the statement if they stick to the rules. A big misconception about the certification rules is that they will affect the United States courts' business judgment rule that gives directors primacy in taking a risk when reviewing decisions. ${ }^{256}$ Critics have argued that this would lead to directors and executives avoiding risks for fear of liability and thereby diminishing economic progress. However, the Act only punishes fraudulent behaviour. ${ }^{257} \mathrm{~A}$ decision made in good faith is not punishable. ${ }^{258}$ A positive effect is that the importance of the audit is emphasised. By linking the responsibility for the audit report directly to the most powerful executives of a company, the audit

248 Branson, above n 22, 1005.

249 Hamilton, above n 3, 60.

250 Branson, above n 22, 1005.

251 Kim, above n 20, 247.

252 Walsh and Thesing, above $\mathrm{n} 85,165$.

253 Hamilton, above n 3, 66.

254 Branson, above n 22, 1004.

255 Branson, above n 22, 1004.

256 For example, knowingly signing a false financial statement: Kim, above n 20, 245.

257 Minter Ellison Rudd Watts, above n 74, 20.

258 Kim, above n 20, 246. 
report comes into the focus of these executives. They can no longer deny responsibility and are forced to cooperate more closely with the auditors. ${ }^{259}$

New Zealand should also adopt a certification requirement for the CEO and CFO. ${ }^{260}$ Other provisions put substantial pressure on auditors. It is beneficial if the responsibility for the accuracy of reports lies with the executives as well. ${ }^{261}$ This way they cannot place the blame solely on the auditor.

\section{Disclosing remuneration}

The German Code recommends that management boards' remuneration be published in detail in the company's financial statement. ${ }^{262}$ The same provision exists for supervisory board members. ${ }^{263}$ However, it only requires disclosing the package for the boards as a whole, without breaking it down to each individual member. ${ }^{264}$

An argument against disclosing remuneration is that shareholders could focus on this topic and get distracted from more important issues. ${ }^{265}$ Nevertheless, transparency is important. ${ }^{266}$ Shareholders have a right to know about performance-based components of remuneration provided to executives as an incentive to work successfully. ${ }^{267}$ In order to judge the incentives in relation to each individual executive, such information has to be broken down by director.

\section{G Remuneration}

Directors' remuneration has become a controversial topic after Enron. Enron's directors earned millions of dollars at a time when the company was practically bankrupt, while employees lost their entire pension funds. ${ }^{268}$ Surprisingly, the United States Act does not explicitly address the topic of remuneration. Only executive loans are dealt with. On the contrary, the German Code encourages

259 Mitchell, above n 143, 1200.

260 The great majority of respondents in the consultation process were in favour of a certification requirement; Corporate Governance in New Zealand: Principles and Guidelines, above n 69, 57.

261 Minter Ellison Rudd Watts, above n 74, 20.

262 German Code, s 4.2.3.

263 German Code, s 5.4.5.

264 Burbidge, above n 24, 650.

265 Minter Ellison Rudd Watts, above n 74, 7-8.

266 Diplock, above n 61.

267 The majority of respondents in the consultation process agreed; Corporate Governance in New Zealand, Principles and Guidelines, above n 69, 58.

268 Kim, above n 20, 237-238. 
the use of variable components of remuneration, some of which have proved controversial during recent scandals. It is questionable whether this will benefit German corporate governance.

\section{The use of stocks and stock options as part of remuneration}

In the United States, stocks and stock options are a common part of directors' remuneration. ${ }^{269}$ Though there has been a substantial amount of misuse in connection with stock options, the Act did not approach this topic. ${ }^{270}$

The German Code suggests that executive remuneration shall consist of variable as well as fixed parts. Variable components shall include one-time and annual components that should be linked to business performance as well as components containing long-term incentives and elements of risk. The Code gives the example of company stocks with a multi-year blocking period or stock options. ${ }^{271}$ The same provisions exist for members of the supervisory board. ${ }^{272}$ The idea is to become more competitive. With executives being increasingly sought internationally, German remuneration policy is thereby brought in line with international standards. ${ }^{273}$ However, the question is whether this is a good development.

The idea behind having flexible components of remuneration based on the company's performance is to align management with shareholder incentives. Executives only earn if the shareholders do well. Stock options are a popular method of flexible remuneration. In the United States they account for more than 70 per cent of the typical CEO remuneration. ${ }^{274}$ Their popularity also derives from the fact that they are not an expense for accounting purposes, but nevertheless are deductible for tax purposes. ${ }^{275}$ However, stock options as management remuneration also have their downsides. The main problem is that they provide short-term incentives for executives. ${ }^{276}$ Having a substantial part of remuneration at stake, executives are likely to focus on the share price at the time options are granted. ${ }^{277}$ The problem is that executives can withhold news at critical points in time in

269 Christina Roschmann "Stock Option Plans in Germany" (1999) 12 SPG INGPRAC 29, 29.

270 Hamilton, above n 3, 69.

271 German Code, s 4.2.3.

272 German Code, s 5.4.5.

273 Ingrid Kalisch "Stock Options: Will the Upcoming Amendment of the German Stock Corporation Act Facilitate Their Introduction by German Stock Corporations" (1998) 9 ICCLR 111, 115.

274 Hamilton, above n 3, 72.

275 David Millon "Why is Corporate Management Obsessed with Quarterly Earnings and What Should be Done About It?" (2002) 70 Geo Wash L Rev 890, 916.

276 Hamilton, above n 3, 70-71.

277 Susan J Stabile "Enron, Global Crossing, and Beyond: Implications tor Workers" (2002) 76 St John's L Rev 815,817 . 
order to influence the stock price. ${ }^{278}$ In other words, stock options provide a strong incentive for short-term focus, which is contrary to the company's interest in long-term wealth. At least German law should provide for a defined period that shares must be held for before they can be sold. ${ }^{279}$ Furthermore, granting stock options dilutes the participation of existing shareholders. ${ }^{280}$ Hence, the benefits of implementing stock options as a principle can at least be doubted. New Zealand should not follow the German approach and should leave the decision on how to design executive remuneration to each company.

\section{Executive loans}

A related topic is the question of company loans to directors or executives. The German Code does not address this question. The Act generally prohibits personal loans for corporate officers and directors. ${ }^{281}$ Before, it was the common practice of United States companies to grant personal loans to leading employees. For example, it was alleged that Tyco's CEO, Denis Kozlowski, was granted a US\$19 million loan that was later forgiven. ${ }^{282}$ Personal loans are legal under Delaware law, which is now superseded by the federal Act. ${ }^{283} \mathrm{Kim}$, however, sees some good reasons to allow such loans. Firstly, he mentions that CEOs have a legitimate interest in receiving a loan when relocating because of the company. Secondly, in his view companies profit from lending money to executives to enable them to buy company stock, because this aligns their interests with those of the company. As to the first point, it is hard to see why a highly paid CEO should be treated differently than any other employee who would not get a loan in such a situation. Conversely, he or she might need the money much more. The Act does allow loans for that purpose, as long as the conditions are on "market terms". As far as the second argument is concerned, a simple number from Enron's story should be sufficient. Enron's CEO, Kenneth Lay, was able by such a credit to purchase stock options that resulted in personal gains of US\$100 million in the year of Enron's collapse. ${ }^{284}$ However, this seems to be an American problem. It would be enough if such loans had to be published in New Zealand.

278 Millon, above n 275, 908-909.

279 Millon, above n 275, 916.

280 Kalisch, above n 273, 116.

281 Hamilton, above n 3, 62.

282 Kim, above n 20, 249.

283 Kim, above n 20, 249.

284 Branson, above n 22, 1008. 


\section{H Shareholder and Stakeholder Interests}

The United States and the German systems provide examples of two completely different corporate philosophies. ${ }^{285}$ While United States corporate law traditionally seeks to protect shareholder interests, modern German law always took other stakeholder interests into account. ${ }^{286}$ It is interesting to analyse recent developments. On the one hand a certain shift in German law towards strengthening shareholders' rights can be recognised. ${ }^{287}$ On the contrary, no shift towards greater stakeholder protection can be seen in the Act or any other new regulation in the United States. If one leaves minor changes aside, ${ }^{288}$ stakeholder participation in corporate governance still does not play any role in United States law. The question is whether this is a misconception.

Burbidge argues that a scandal like Enron might not have happened if the supervision of directors was in the hands of a wider range of stakeholders as in Germany. ${ }^{289}$ Referring to the German situation this can only mean two groups of stakeholders: creditors ${ }^{290}$ and employees. ${ }^{291}$ The question arises whether stakeholders could be important and motivated monitors of the company.

The first possibility is the assignment of a greater role to banks. In Germany, banks as large shareholders play an important role in monitoring management. ${ }^{292}$ In the United States, banks cannot contribute much, due to the fact that they are not allowed to hold shares. ${ }^{293}$ Hence, they are not in a meaningful position for monitoring. Instead, the focus in the United States has shifted to institutional investors. ${ }^{294}$ They hold substantial assets and have the financial resources and administration to effectively monitor companies. ${ }^{295}$ However, until now they have failed to do so

285 Kissane, above n 76, 649.

286 "A Missing Link", above n 13, 457-459.

287 The Code tries to give attention to shareholders' concerns. Most notably, this includes facilitating the use of proxies and representatives to exercise shareholder voting that are available for shareholders during the general assembly (Section 2.3.3 of the German Code); "Germany: The German Corporate Governance Code: Co-Determination And Corporate Governance Reform", above n 33, 52.

288 Like the prohibition for directors to sell stock in blackout periods when employees are prohibited from selling: Stabile, above n 277, 832 .

289 Burbidge, above n 25, 644-645.

290 Banks playing a major role in German corporate law: Brett H McDonnell "The Curious Incident of the Workers in the Boardroom" (2000) 29 Hofstra L Rev 503, 516 ["The Curious Incident"].

291 "A Missing Link", above n 13, 474.

292 "A Missing Link", above n 13, 459.

293 Roe, above n 9, 1948-1950.

294 Gelb, above n 136, 523.

295 "The Review of the Role" above n 30, 264. 
and rather exited companies stock instead of becoming active in changing corporate behaviour. ${ }^{296}$ Could banks play an important role in monitoring New Zealand companies? This cannot be prescribed by principles or law, but is a question of changing banks' and other institutions' attitudes towards their responsibility for corporate governance.

The second group of stakeholders to potentially monitor directors are employees. There are two ways to realise such participation. Firstly, employees can be stockowners and thereby have the same rights as other shareholders. ${ }^{297}$ However, in times of company crisis this could prove fatal. ${ }^{298}$ Employees could not only lose their jobs, but also their savings. Again Enron provides a good example. ${ }^{299}$ The second possibility is giving employees a voice in the corporation, like German law does. The main criticism against employee participation in corporate governance is that their interests are contrary to those of the shareholders. ${ }^{300}$ Employees are interested in higher wages and job security. ${ }^{301}$ Therefore they want to keep as much money in the company as possible. ${ }^{302}$ Shareholders are interested in obtaining dividends and rising stock prices. ${ }^{303}$ There seems to be a conflict between employees' long-term and shareholders' short-term interests. However, taking a closer look, it may be in the long-term interest of the company not to focus on shareholders' shortterm interests. Burbidge concludes that "excessive focus on 'shareholder value' is unhealthy for the company, the employees and ultimately for the shareholders themselves" because it affects the company in the long run. ${ }^{304}$ In other words, involving employees (or other stakeholders) in governing the corporation might be in the company's best interest. ${ }^{305}$ Especially for a country like New Zealand, where companies have always had a very high dividend payout compared to international standards, ${ }^{306}$ such an approach is worth considering. ${ }^{307}$ Furthermore, there are other

296 Following the so-called "Wall Street rule"; Stephen M Bainbridge "The Politics of Corporate Governance" (1995) 18 Harv J L \& Pub Pol'y 671, 695-696.

297 Burbidge, above n 25, 657.

298 "The Curious Incident" above n 290, 508.

299 Stabile, above n 277, 822.

300 "The Curious Incident" above n 290, 512.

301 Dana Muir "Groundings of Voice in Employee Rights" (2003) 36 Vanderbilt J Transnat'l L 485, 512.

302 "A Missing Link", above n 13, 452-453.

303 Marsha Cope Huie "Antitrust and Corporate Dividend Policy: Revising Dividend Payment Policies to Empower Shareholders to Curb Mergers and Acquisitions" (1993) 25 St Mary's L J 243, 259.

304 Burbidge, above n 25, 662 .

305 Muir, above n 301, 512.

306 Healy, above n 59, 210.

307 The consultation process showed strong - though often modified - support for considering stakeholders' interests: Corporate Governance in New Zealand: Principles and Guidelines, above n 69, 73. 
advantages to employee participation. Employees see the company from a management perspective, which should improve their understanding of decisions. ${ }^{308}$ Another advantage is improved loyalty of employees to "their" company, as can be observed in German or Japanese firms. ${ }^{309}$ Moreover, employees know their company in depth. ${ }^{310}$ This enables them, for example, to contribute to improving production processes. ${ }^{311}$ Apart from that, they know management from day-to-day experience and hence can judge their performance first hand. ${ }^{312}$ Finally, it should not be forgotten that shareholders and employees have some important common interests, like controlling directors' powers and keeping their remuneration down. ${ }^{313}$

This topic has not been addressed in the United States or the United Kingdom. ${ }^{314}$ While such an approach must not be as extensive as in Germany, thereby avoiding the downsides of large board size and international criticism, it might be worth considering involving at least one employee representative in the boards of larger New Zealand companies.

\section{Other Topics}

There are some other rules and contents in the Act and the Code which are briefly outlined below.

\section{$1 \quad$ Installation of an accounting oversight board}

The Act creates the Public Company Accounting Oversight Board (PCAOB). Each accounting firm that provides audit services to at least one public firm is subject to registration with the PCAOB. The PCAOB will establish auditing, ethics, independence, and other standards for auditing companies and will oversee compliance, ${ }^{315}$ including yearly inspections of the largest audit companies. ${ }^{316}$ It can impose sanctions as serious as permanent suspension on non-compliant audit companies. ${ }^{317}$ The Board itself is appointed and overseen by the SEC. ${ }^{318}$ The PCAOB's

\footnotetext{
308 Burbidge, above n 24, 662.

309 "A Missing Link", above n 13, 467.

310 "A Missing Link", above n 13, 475.

311 "The Curious Incident" above n 290, 504.

312 Muir, above n 301, 511-512.

313 Burbidge, above n 25, 662.

314 Burbidge, above n 25, 662.

315 Hamilton, above n 3, 56.

316 Branson, above n 22, 1010.

317 Kim, above n 20, 241.

318 Hamilton, above n 3, 57.
} 
composition reflects an attempt to establish an independent oversight unit. Only two of its five members are allowed to be current or former certified public accountants. ${ }^{319}$ Moreover, if the chairperson is one of the two former accountants, they are not allowed to have practised within five years of being appointed. ${ }^{320}$

The question remains whether the implementation of such a body is advisable in New Zealand. Due to the outstanding importance of auditing, an independent body overseeing accounting companies has some merit. However, such a body demands some experts to run it effectively. This will prove costly. Nevertheless, the Commission suggested implementing such an entity in New Zealand, despite the fact that the majority of respondents in the consultation process were against it. ${ }^{321}$ The Commission pointed to the potentially positive contribution the entity could have to the integrity of the New Zealand capital market. ${ }^{322}$ It remains to be seen if the government will follow the Commission's advice.

\section{Whistleblower protection and attorney reporting obligations}

The Act also contains provisions to ensure that whistleblowers and analysts are not punished for unfavourable reports. ${ }^{323}$ Such protection is important in order to encourage people to speak up in the case of a developing crisis. ${ }^{324}$ Timely warnings may prevent more serious developments.

The Act's obligations on attorneys go a step further. Lawyers who practise or appear before the SEC must report any "evidence" of securities law violations or breaches of fiduciary duty to their client's or employee's in-house lawyers. If those do not react "appropriately" they have to report the violations or breaches to the client's audit committee. If this still leads to no solution the attorney has to "noisily withdraw" and report to the SEC. The attorney's position has been described as a "watchdog". ${ }^{325}$ This regulation arguably overshoots the mark. It causes severe problems concerning attorney-client privilege. The more general question arises whether a company's lawyer is the "hired

319 Kim, above n 20, 241.

320 Hamilton, above n 3, 57.

321 Corporate Governance in New Zealand: Principles and Guidelines, above n 69, 7.

322 Corporate Governance in New Zealand: Principles and Guidelines, above n 69, 7.

323 Hamilton, above n 3, 66.

324 A great majority of respondents in the consultation process agreed: Corporate Governance in New Zealand: Principles and Guidelines, above n 69, 67.

325 Hamilton, above n 3, 61 . 
gun" of the company or whether an attorney has superior obligations to the public in certain cases. $^{326}$

\section{Explanation of the legal system}

Large parts of the German Code do not implement any new rules, but explain the German legal system. ${ }^{327}$ While this primarily has to do with peculiarities of the German system, such as codetermination and the dual board structure, New Zealand could nevertheless consider explaining its corporate legal system to international investors. New Zealand could investigate whether international investors are sufficiently informed about its corporate system. In the event that there is insufficient information, it might be a good idea to include a provision in New Zealand's code of corporate governance briefly explaining its legal background. However, New Zealand should avoid the mistakes made in the German Code. The German Code mixes the simple reproduction of existing legislation with the principles suggested. There is a constant shifting between recommendations and mandatory legislation. This results in a lack of clarity and further confuses investors. ${ }^{328}$ There should be a separate paragraph before the principles or as part of the foreword.

\section{CONCLUSION}

No matter how New Zealand responds to the recent events in corporate governance, one thing should be kept in mind. No code or legislation can entirely eliminate corporate failure. ${ }^{329}$ Such failures can only be prevented by a change of behaviour. However, thoughtfully designed rules may at least reduce the risk to a minimum. This is what makes them important.

This article has provided an overview of the latest changes in German and United States corporate governance. It has shown that it makes sense for New Zealand to adopt certain provisions from both approaches. Most importantly, New Zealand should adopt a principles-based approach. As to the question of principles to implement, it is a fine line between achieving reasonable standards to improve corporate governance and imposing unnecessary burdens on companies. ${ }^{330}$ It will be crucial for New Zealand to find a compromise between the two.

One thing remains to be said. Corporate governance cannot be regulated once and then forgotten about. Constant review is important to ensure the principles are kept up to date and are suitable for

326 This question is beyond the scope of this paper; For further discussion, see Christina R Salem "The New Mandate of the Corporate Lawyer After the Fall of Enron and the Enactment of the Sarbanes-Oxley Act" (2003) 8 Fordham Int'l L J 765.

327 Wolff even calls it a "marketing gimmick"; Wolff, above n 5, 115.

328 "Germany: The German Corporate Governance Code: Co-Determination And Corporate Governance Reform", above n 33, 354.

329 Kim, above n 20, 252.

330 Quinn, Rowe and Linton, above n 93, 1-2. 
the current business environment. The German Code will be reviewed and adjusted annually. ${ }^{331}$ New Zealand should do the same.

331 Wolff, above n 5, 121. 